Journal of Primary Education
$9(5)(2020): 482-492$
UNNES
https://journal.unnes.ac.id/sju/index.php/jpe

\title{
Flash Interactive Media to Improve the Mastery of Light Properties Concept
}

\author{
Mitasari Widyaningsih $^{1 \bowtie}$, Samsudi Samsudi ${ }^{2}$, Ellianawati Ellianawati ${ }^{2}$ \\ DOI: https://doi.org/ 10.15294/jpe.v9i5.42991 \\ ${ }^{1 .}$ SD Negeri 1 Blimbing, Kecamatan Karangnongko, Kabupaten Klaten, Indonesia \\ 2. Pascasarjana, Universitas Negeri Semarang, Indonesia
}

\begin{tabular}{l} 
Article Info \\
\hline History Articles \\
Received: \\
19 August 2020 \\
Accepted: \\
17 Sebtember 2020 \\
Published: \\
30 December 2020 \\
\hline Keywords: \\
Flash Interactive \\
Media, Learning \\
Motivation, Concept \\
Understanding, \\
Learning science
\end{tabular}

Learning science

\begin{abstract}
The purpose of this study is to analyze the effect of flash interactive media in improving students' understanding of concepts in elementary schools. This type of research was mixed methods with an embedded experimental model design. Quantitative data analysis techniques on the variable understanding of the concept, namely the results of the analysis of the students' pretest and posttest questions by using paired sample t-test. The results of the analysis are then triangulated with the qualitative Focus Group Discussion (FGD) data and the results of the interviews. This study involved 54 students who were selected by using the nonprobability sampling technique: purposive sampling. The population consists of 31 public schools and 13 private schools. The results of this study show a significant increase in the concept of understanding in the form of an increase in the average score understanding of concepts by $17.82 \%$. According to questionnaire data that has been distributed, teachers and students respond very well to learning using the flash interactive media. Students' motivation to learn accompanies an increase in their understanding of concepts. It appears that the application of flash interactive media in science learning has a positive impact on increasing motivation that has an impact on increasing students' conceptual understanding.
\end{abstract}




\section{INTRODUCTION}

(Kemdikbud, 2016) States that the learning process in educational units should be held in an interactive, inspirational, fun, challenging, motivating students to participate actively, and provide sufficient space for the initiative, creativity, and independence according to the talents, interests, and physical and psychological development of students. For this reason, each education unit must conducts the lesson planning, implementation of the learning process, and assessment of the learning process to improve the efficiency and effectiveness of the achievement of graduate competencies. A'yun \& Subali (2019), said that to improve the science learning process it can be seen from how good the classroom conditioning is in creating and developing a learning atmosphere. To create an attractive learning atmosphere, learning media can be assisted.

Media has a crucial role in learning. As a tool, the media can help teachers to facilitate learning to be more meaningful. According to Tafonao (2018) learning media is anything that can be used to transmit the sender's message to the recipient so that it can stimulate students' thoughts, feelings, attention, and interest in learning. The results of the study according to Mulyati \& Nugrahani (2019) that various flash card-based learning media shows a good performance for learning. Teachers as instructors are expected to be able to use their abilities optimally to encourage students' abilities to produce contextual works, both individually and in groups. Teachers are strongly advised to use a learning approach that produces project-based learning (Kemdikbud, 2016). Furthermore, Karsono et al. (2019) said that that learning by using a variety of different learning media at each meeting has a positive impact on the students. It can be seen from the increase in the average learning outcomes of students.

According to Isti et al. (2020), the efforts to use technological advances into learning media that can provide direct experience must be under the characteristics of learning in the 2013 curriculum. Thus, it is expected that a teacher should avoid using the monotonous and continuous lecture method as much as possible. This is feared that it will reduce student motivation and result in decreased achievement. This is in line with the findings of Rahmaibu et al. (2016) that learning problems that occur in schools are the main cause of the lack of student motivation in learning. Students who are passive in learning tend to have a low understanding of concepts.

Based on the results of observations in one elementary school, many students have difficulty understanding the learning material. One of the reasons is the quantity of learning material that is too much but the availability of learning resources is still limited. On the other hand, teachers have not used multimedia-based learning media as a teaching aid for the lecture method that has been used so far. Besides that, the parents' time-consuming work background causes a lack of concern for the child's learning process at home.

In accordance with the Hidayatullah (2020) adobe flash-based learning affects the interaction between students and teachers more dynamically and creates comfortable learning conditions. Good learning is learning that involves the active attitude of students as learning subjects. Students who are actively involved and motivated in learning activities will have an impact on increasing the understanding of concepts. One of the ways to increase motivation and conceptual understanding is by using the learning media. Based on research conducted by Yeni (2011), it is known that learning models that utilize manipulative objects can improve the students' understanding of geometric concepts and the ability of spatial insight. The results of this research are in the form of flash interactive media which is designed to improve students' understanding of concepts by presenting virtual objects. So, students can still enjoy the experience of virtual science experiments. According to Prasetyo \& Prasojo (2016), the development of adobe flash media in increasing student achievement. The student learning process increased seen from the 
mean percentage of the pretest and posttest scores.

A'yun \& Subali, (2019), The process of learning science in elementary schools requires teachers to be creative as possible so that they can deliver material in detail according to the concept of science learning which is not only through lectures but also must involve the active student participation. Some science materials require a good understanding to be accepted by students because not all of the symptoms can be observed directly. For example, the properties of light where the whole material cannot be understood continuously by students. Students are more familiar with some of the concepts than the whole process which can be observed directly around them. Therefore, in presenting the material should be able to use the facilities to grasp the concept as a whole. These facilities are none other than learning media that help in the learning process.

Based on these problems, the purpose of this study is to analyze the application of flash interactive media so that it can be used to improve students' motivation and conceptual understanding of the material properties of light.

\section{METHOD}

This study used mixed methods research. The research design in this study used an embedded experimental model design. The experimental mix was a study that encloses a basic mixed methods design in an experiment.

The sample was chosen as the fourthgrade students of SD N Ngesrep 02, totaling 28 students as the control class who still used conventional learning methods and SD N Ngesrep 03, which amounted to 26 students as the experimental class implementing flash interactive media-based learning.

The variables in this study consisted of independent variables, namely the application of flash interactive media, the dependent variable, namely understanding the concept. The data collection techniques were: test and non-test. The test used was a written test with 20 multiple choice questions to measure the level of students' understanding in the form of learning outcome data before and after students learned using flash interactive media. Non-test, namely a response questionnaire with 5 measuring indicators with 10 statements that were used as observation sheets to determine the initial conditions of students and teachers before the research was carried out, while the data collection instruments were interview guides, observations, and surveys, learning motivation questionnaires, FGD.

Data analysis techniques included: instrument validity test, instrument reliability test, normality test, homogeneity test, statistical hypothesis test separated variant t-test, independent sample t-test statistical hypothesis test. The study also used a data validity test in the form of triangulation in 2 (two) stages, namely analyzing qualitative and quantitative data separately then combining qualitative and quantitative data to determine the interpretation results with quantitative primary data. This triangulation was used so that the interpretation and results of the research were completely the same between the quantitative database and the qualitative database or the theoretical database with the empirical database.

\section{RESULTS AND DISCUSSION}

This study uses two classes, namely the experimental class that applies flash interactive media, and the control class which only applies student activity sheets with simple media as a comparison to science learning with the material properties of light.

Initial data in the form of student learning outcomes are taken before the media used is applied to either the experimental class or the control class which is then used as a prerequisite test in the study. To analyze the data in this study, the conceptual understanding of data is tested firstly by the prerequisite test for normality and homogeneity. The results of the normality and homogeneity test can be seen in Tables 1 and 2. 
Table 1. Normality Test Result

\begin{tabular}{llll}
\hline Data & Kolmogorov-Smirnov Z & Sig. (2-tailed) & Description \\
\hline Pretest Control & 1.112 & 0.169 & Normal \\
Pretest Experiment & 0.854 & 0.459 & Normal \\
Posttest Control & 1.263 & 0.082 & Normal \\
Posttest Experiment & 1.026 & 0.243 & Normal \\
\hline
\end{tabular}

In Table 1, the prerequisite test data for normality requirements that have been carried out show that the sample comes from a normally distributed population, this is evident from the asymp results. Sig. (2-tailed) on each data on the concept of understanding, both pretest and posttest are more than $\alpha(0.05)$.

Table 2. Homogeneity Test Results for the control and experimental classes

\begin{tabular}{llll}
\hline Data & Levene Statistic & Sig. (2-tailed) & Description \\
\hline Pretest & 0.605 & 0.44 & Homogenous \\
Posttest & 3.489 & 0.067 & Homogenous \\
\hline
\end{tabular}

In Table 2, the prerequisite test data for homogeneity requirements that have been carried out show that the samples come from the same population (homogeneous samples), this is evident from the results of Sig. (2-tailed) on the conceptual understanding data, both pretest and posttest are more than $\alpha(0.05)$.

Intan et al. (2018), The t-test is used to determine the effect of the treatment given on the sample on the students' concept mastery ability. Further data could be processed using statistical tests parametric namely Paired Sample T-Test, Independent sample t-test and data analysis of the relationship between motivation and the increased understanding of concepts using the Pearson Correlations statistical test as presented in Table 3.

Tabel 3. Test Results Paired Sample T-Test Conceptual understanding

\begin{tabular}{|c|c|c|c|c|c|c|c|}
\hline Data & & $\begin{array}{l}\mathrm{Me} \\
\text { an }\end{array}$ & $\begin{array}{l}\text { Mean } \\
\text { different }\end{array}$ & $\begin{array}{l}\text { Std. } \\
\text { Deviatio } \\
\mathrm{n}\end{array}$ & $t_{\text {countin }}$ & $\begin{array}{l}\text { Sig. (2- } \\
\text { tailed) }\end{array}$ & Description \\
\hline \multirow{3}{*}{$\begin{array}{l}\text { Control } \\
\text { Class }\end{array}$} & Pre-test & $\begin{array}{l}66 . \\
96\end{array}$ & - & 6.71 & - & - & \\
\hline & Post-test & $\begin{array}{l}73 . \\
21\end{array}$ & - & 4.13 & - & - & \\
\hline & $\begin{array}{l}\text { Paired } \\
\text { Sample }\end{array}$ & - & 6.25 & 7.15 & -4.62 & 0.00 & $\begin{array}{l}\text { There is a Significant } \\
\text { Difference }\end{array}$ \\
\hline \multirow{3}{*}{$\begin{array}{l}\text { Experiment } \\
\text { Class }\end{array}$} & Pre-test & $\begin{array}{l}67 . \\
50\end{array}$ & - & 6.96 & - & - & \\
\hline & Post-test & $\begin{array}{l}78 . \\
27\end{array}$ & - & 5.47 & - & - & \\
\hline & $\begin{array}{l}\text { Paired } \\
\text { Sample }\end{array}$ & - & 10.77 & 7.17 & -7.66 & 0.00 & $\begin{array}{l}\text { There is a Significant } \\
\text { Difference }\end{array}$ \\
\hline
\end{tabular}


The data in Table 3 shows a significant difference between the initial concept of understanding data and the final concept of understanding data in both the control class and the experimental class. This is indicated by the sig value. (2-tailed) of $0.000<\alpha$ for significance of 0.05 . The magnitude of this difference is also shown in the pretest and posttest means which have a mean difference of 6.25 in the control class and 10.77 in the experimental class.

The next test is to compare the results of students' conceptual understanding who get conventional learning methods (control class) with the conceptual understanding of students who get the learning method using flash interactive media. The results of the comparative test are interpreted in Table 4 below.

Table 4. The Results of the Independent Sample T-Test for Students' Concept Understanding

\begin{tabular}{llll}
\hline Data & $t_{\text {count }}$ & Sig. (2-tailed) & Description \\
\hline Posttest Understanding the Concept & -3.851 & 0.00 & There is a Significant Difference \\
\hline
\end{tabular}

In Table 4, it is found that there is a significant difference between the posttest understanding of the concept of the control class and the experimental class. This is indicated by the sig value. (2-tailed) of $0.000<\alpha$ for significance of 0.05 . Because there are significant differences, the test is continued by looking at the average results of understanding the concept. In Table 3, it can be found that the posttest means a score of understanding the concept of the control class is 73.21 and the experimental class is 78.27. Based on these results, it can be seen that the average value of conceptual understanding in the experimental class is higher than the control class. So it can be concluded that the average results of students 'understanding of concepts with the application of flash interactive media in learning are higher than students' understanding of concepts with conventional learning models.

The comparison of students' conceptual understanding in science learning in the control class and the experimental class is interpreted in a comparison chart. The conceptual understanding graph is shown in Figure 1 and Figure

2.

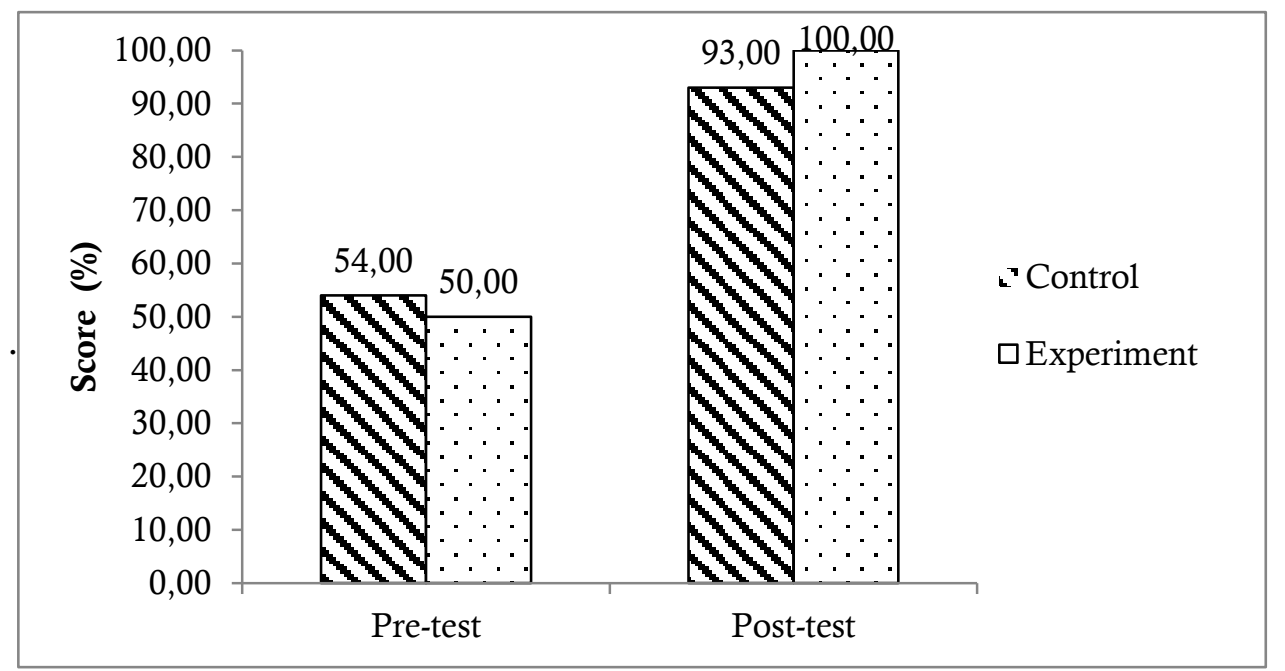

Figure 1. Graph of Students' Individual Completeness of Concept Understanding

Figure 1 shows the number of students who complete the minimum mastery criteria (KKM) 70 at the pretest and posttest. The increase in the number of students who completed the minimum mastery criteria in science learning before and after implementing 
flash interactive media in the experimental class

lower than those using flash interactive media. was $50 \%$ while in the control class it is $39 \%$

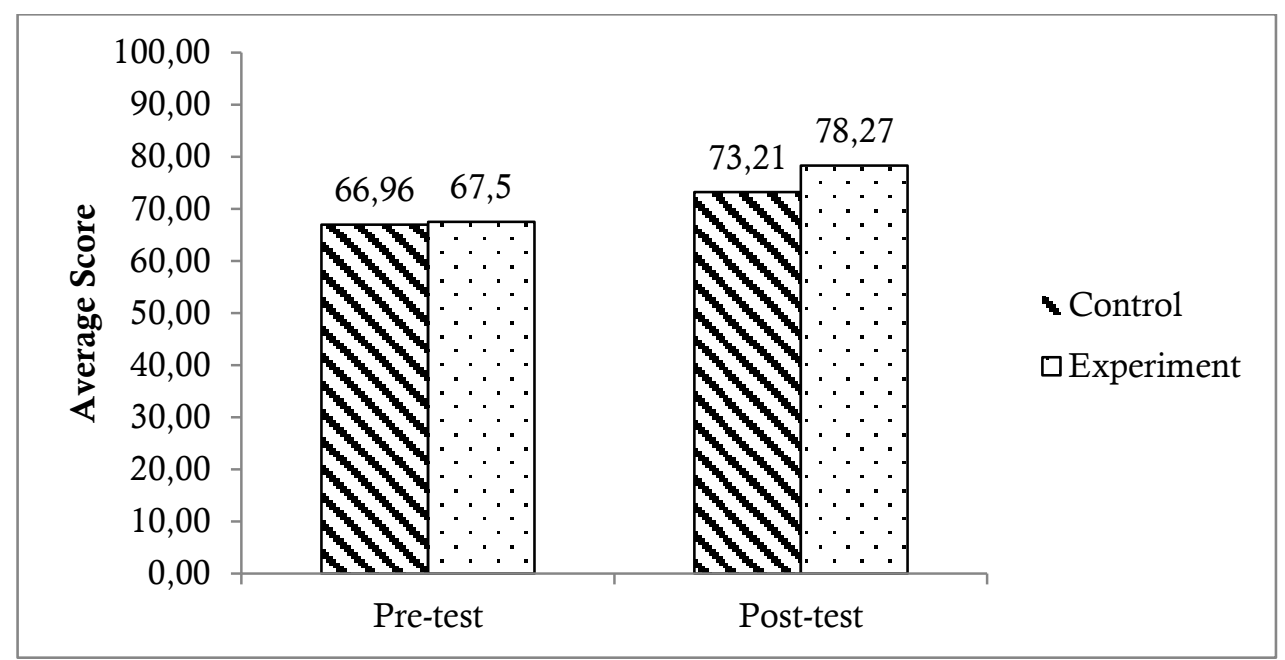

Figure 2. Graph of Students' Average Understanding of Concepts

In Figure 2, the average score of students after implementing flash interactive media in science learning can increase by $10.77 \%$ while the class with conventional methods is only $6.52 \%$. It can be concluded that the application of flash interactive media in science learning is more effective in increasing students' understanding of concepts.

From the results of interviews, Focus Group Discussions (FGD), and questionnaires, it is found that the teacher responds well to the application of flash interactive media.
The teacher assesses that most or more students are interested in being more active in participating in learning so that students' understanding of concepts increases. Students also respond well to the application of flash interactive media. Students consider this media to be able to increase their understanding of their concepts better.

Students' responses to the implementation of science learning using flash interactive media consist of 5 indicators with 10 statements. The student responses can be seen in Figure 3. 


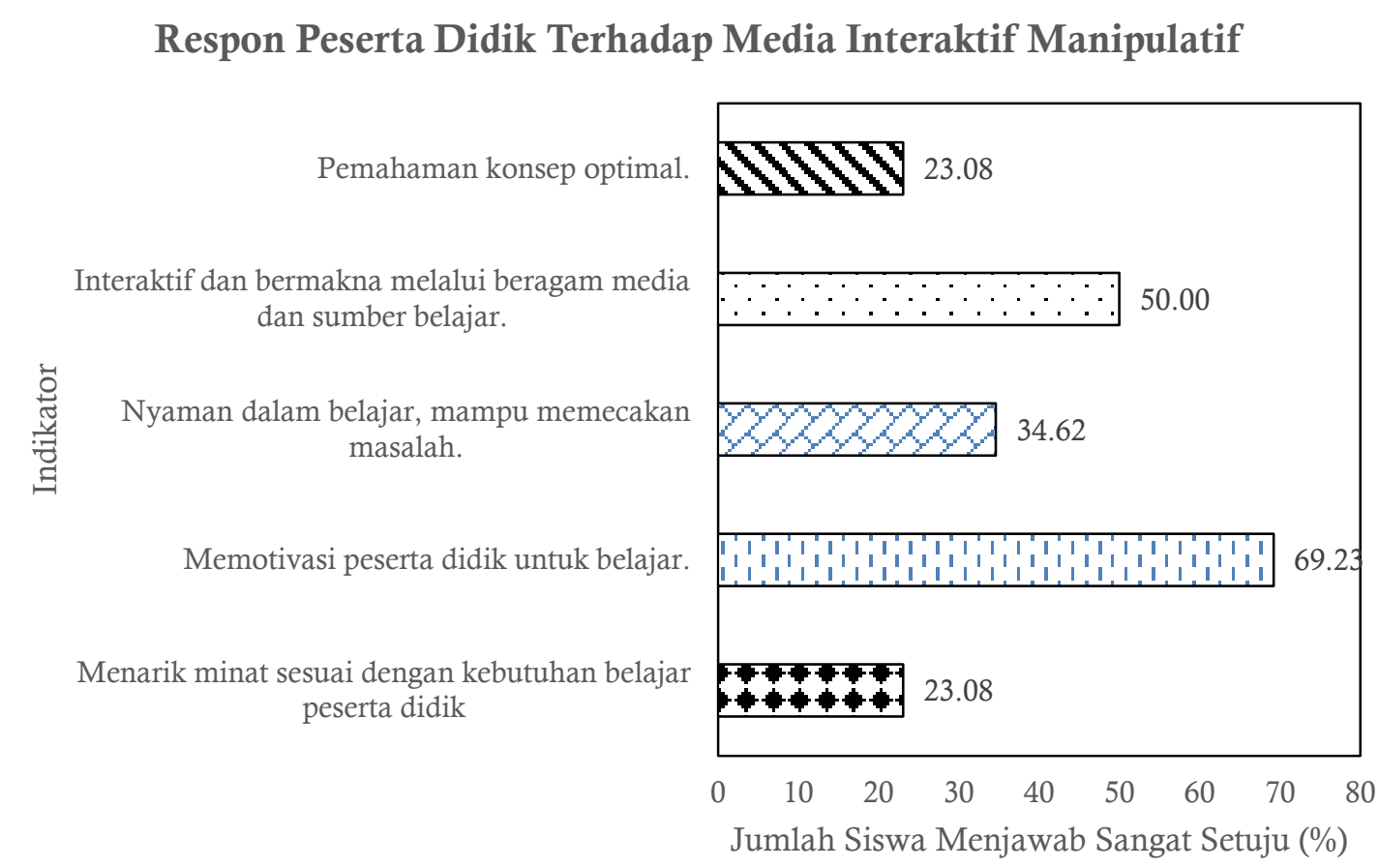

Figure 3. Graph Student Response To Flash Interactive Media

Based on Figure 3 shows the highest response is $69 \%$ of students are motivated to learn, and the lowest response is $23 \%$ of students who strongly agree about flash interactive media in attracting interest according to student learning needs and more optimal understanding of concepts. This means that $22 \%$ to $69 \%$ of the indicators of learning success is felt well by students while participating in science learning using flash interactive media in the experimental class.

Media that is used effectively and efficiently in learning has a positive impact on increasing understanding of concepts. This can be seen from the increase in the initial concept understanding score with the final concept understanding score and the experimental class students 'concept understanding score better than the control class students' concept understanding score.

Based on the results of the paired sample t-test in Table 3 by comparing the scores obtained from the conceptual understanding questionnaire before and after the intervention, students' conceptual understanding during the science learning process using flash interactive media and conventional methods both experienced a significant increase. It is proven that the Asymp value is obtained. Sig. (2-tailed) is worth 0.000 less than the critical research limit of 0.05 , then $\mathrm{H} 1$ is accepted. This means that there is a difference between understanding the initial concept and understanding the final concept. Furthermore, based on the average value, it shows that the score of understanding of the concept of the experimental class is greater than the score for understanding the concept of the control class with a mean different value of 6.25 at SD Ngesrep 02 and 10.77 at SD Ngesrep 03, this means an increase in the average score understanding the concept from conventional learning models to learning models with interactive flash interactive media by $4.52 \%$. So it can be said that there has been an increase in students conceptual understanding after the implementation of flash interactive media during the learning period.

Furthermore, based on the results of the independent sample t-test on the average score of the questionnaire acquisition of the control class students' concept understanding with the experimental class. Students 'understanding of 
concepts during the science learning process using flash interactive media is better than students' understanding of concepts subject to conventional learning models. It is proven that the Asymp value is obtained. Sig. (2-tailed) is worth 0.000 less than the critical research limit of 0.05 , then $\mathrm{H} 1$ is accepted. This means that there is a significant difference between the control class students 'conceptual understanding and the experimental class students' conceptual understanding. Beside that, based on the average value, it shows that the students 'concept understanding score in the experimental class is higher than the control class students' concept understanding score, namely 78.27 and 73.21. So, it can be said that there is an effect of the application of flash interactive media on increasing student understanding of concepts.

Students' understanding of the concepts that are obtained in this study is the cognitive ability of students in obtaining meaning from the subject matter that has been studied. Students understand or know what is being taught; know what is being communicated; and can explain in its sentence structure, as well as provide other examples similar to the material previously presented.

The use of instructional media in explaining a concept must be following the consideration of media selection. Media that is used effectively and efficiently in learning can improve conceptual understanding. In accordance with Iwantara et al. (2014) learning media is a medium that can create a pleasant learning atmosphere so that it can increase learning motivation and ultimately improve students' understanding of concepts.

in accordance to the research conducted by Prasetyarini et al. (2013) explained that the use of science teaching aids can be used as an alternative to improve understanding of physics concepts. This means that the use of media in the form of aids can improve understanding of the concept.

Learning science with the properties of light by using flash interactive media can increase student interest in learning. Students seem enthusiastic about participating in learning and are actively involved in the learning process.

In learning the concept of light, students still have difficulty understanding the subject matter and relating the relationship between concepts in experimenting. This difficulty has been tried to overcome by providing a display designed according to the learning needs of students. Sugita et al. (2020) explaine that in packaging learning, teachers are encouraged to be more active in asking students to carry out experimental activities in the form of experiments or lab work. The initial appearance of this flash interactive media is a background consisting of blue sky, clouds and colorful rainbows. The title describes the main material of this medium. As well as instructions to the next page in the form of a material button, an experiment button and an exit as in Figure 4.

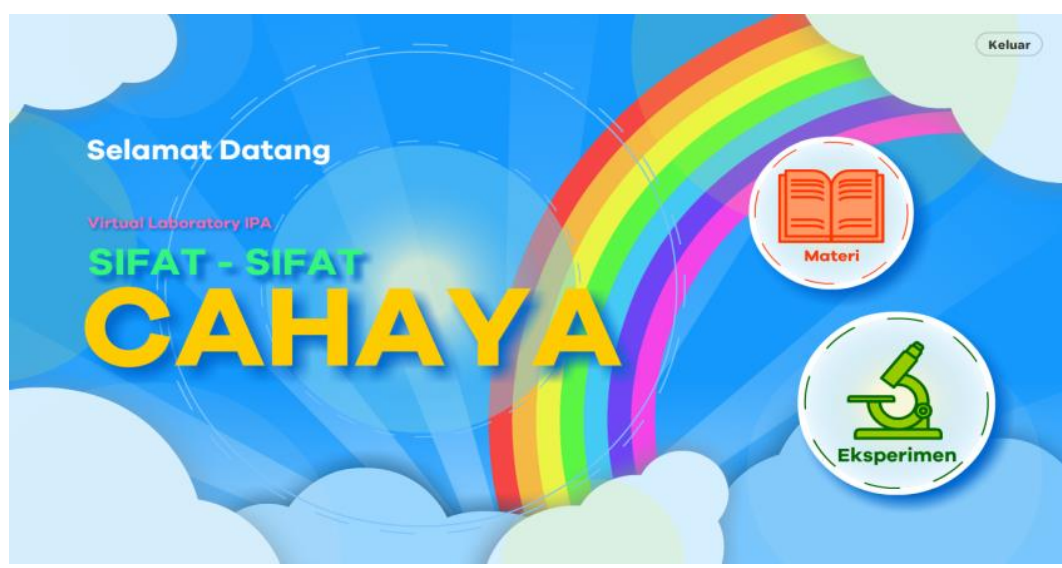

Figure 4. Initial display of flash interactive media 
According to Alamanda (2017), to overcome misconceptions that are often experienced by students, a learning model is needed that can provide understanding to students, especially in the concept of the properties of light. Figure 4 is a simplified initial view of the media to focus more on educational goals. This display consists of material and experiments that will be carried out virtually by students. The material in flash interactive media is focused on explaining the properties of light. Where each material is accompanied by a sound that accompanies the presentation of the material as presented in Figure 5.

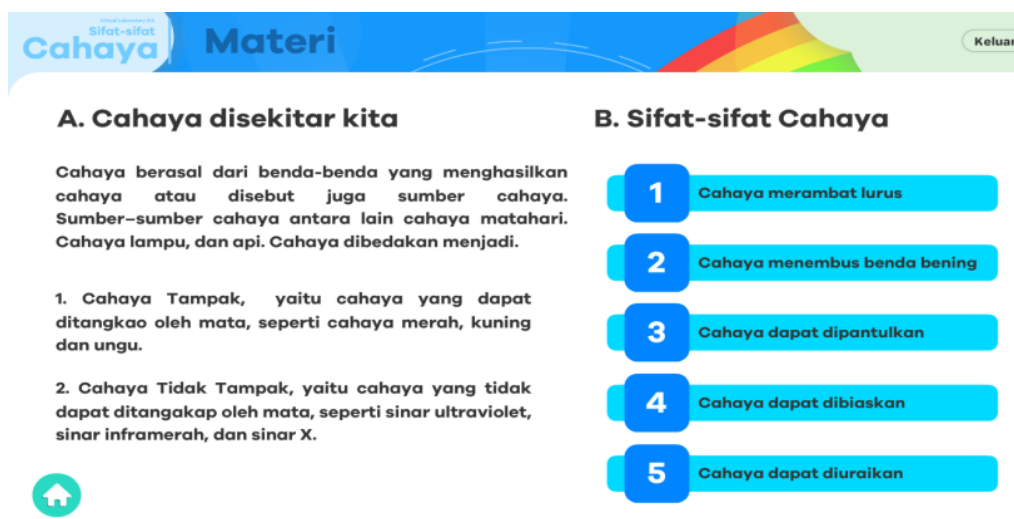

Figure 5. Display of material properties of light on flash interactive media

According to Triyanti (2015), the use of interactive media has the potential to increase student motivation before learning and after learning. One of the features that increase student motivation is the virtual experimental activities as shown in Figure 6.

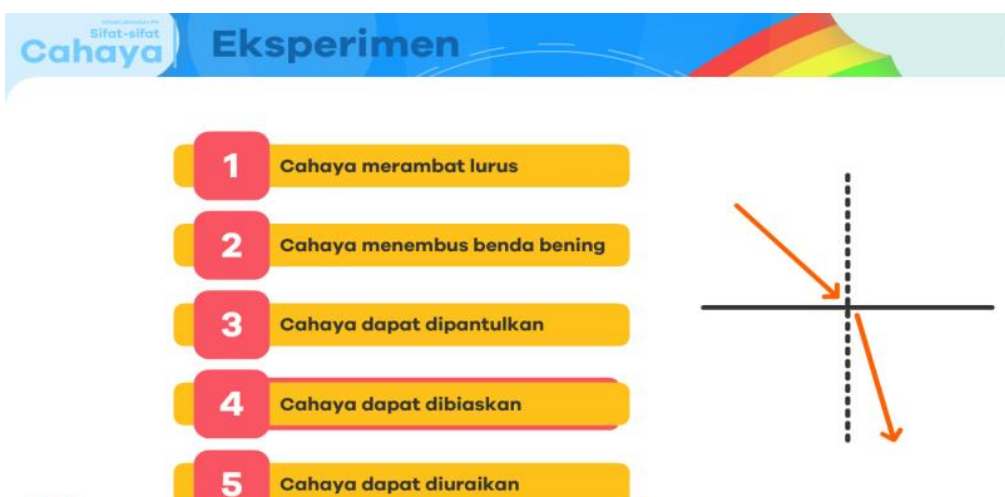

Figure 6. Experimental Display Of Light Properties On Flash Interactive Media

In Figure 6, each material on the properties of light is equipped with an experiment that aims to increase students' conceptual understanding of the properties of light. By accessing virtual experiments students can observe the phenomenon of light propagation and have a more meaningful experience. One example of a virtual experiment that is developed in this study is the properties of light propagation as shown in Figure 7 . 


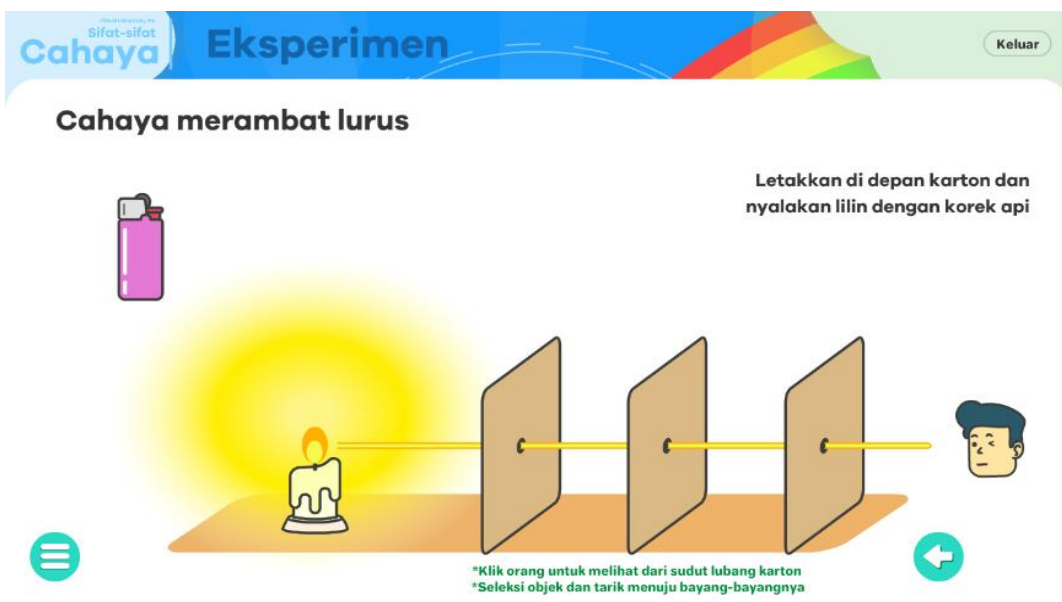

Figure 7. Displays of the experiment with flash interactive media

Based on Nomleni \& Manu (2018), the use of audiovisual aids can improve the concept of understanding in both the control class and the experimental class. So that the arrangement of this flash interactive media does not rule out the audiovisual following Figure 6 showing one of the displays in the straight propagating light experiment which is equipped with supporting audio and attractive visuals.

This study found that the use of flash interactive media affected students' understanding of concepts. Improving in the mean score of understanding. Flash interactive media encourages students to be actively involved in learning. The application of flash interactive media is highly recommended for use in learning, especially science subjects at the elementary school level. Besaide that, there is a positive and significant direct effect of the application of flash interactive media on students' learning motivation and conceptual understanding which is supported by FGD data and response questionnaires.

\section{CONCLUSION}

Hypothesis test results show that the interactive media Flash has a significant effect of $0.000<\alpha$ for significance of 0.05 . Increased understanding of concepts with an average score obtained from a different mean value of 6.25 in the control class and 10.77 in the experimental class. From the results of the teacher's questionnaire assessment Most or more students are interested in being more active in participating in learning and student response questionnaires shows the highest response $69 \%$ of students are motivated to learn.

\section{REFERENCES}

A'yun, S. N., \& Subali, B. (2019). Sifat-Sifat Cahaya Dalam Discovery Learning Untuk Meningkatkan Keterampilan Proses Sains. Jurnal Ilmu Pendidikan, 24(2), 75-79.

Isti, L. A., Agustiningsih, A., \& Wardoyo, A. A. (2020). Pengembangan Media Video Animasi Materi Sifat-Sifat Cahaya Untuk Siswa Kelas IV Sekolah Dasar. EduStream: Jurnal Pendidikan Dasar, 4(1), 21-28.

Alamanda, G. C. (2017). Penerapan Model Pembelajaran Experiental Learning terhadap Perubahan Konseptual Siswa pada Materi Sifat-Sifat Cahaya. Jurnal Penelitian Pendidikan, 17(1), 28-34.

Iwantara, I. W., Sadia, I. W., \& Suma, K. (2014). Pengaruh penggunaan media video youtube dalam pembelajaran IPA terhadap motivasi belajar dan pemahaman konsep siswa. Jurnal 
Pendidikan Dan Pembelajaran Ipa Indonesia, 4(1) 13-26.

Karsono, K., Alimah, S., \& Bintari, S. H. (2020). Pemanfaatan Ragam Media Belajar Pada Materi Sains Di Sekolah Dasar. Bioeduca: Journal of Biologi Education, 1(1), 55-61.

Pendidikan, M., \& Indonesia, K. R. (2016). Peraturan Menteri Pendidikan dan Kebudayaan nomor 24 tahun 2016 tentang kompetensi inti dan kompetensi dasar pelajaran pada Kurikulum 2013 pada pendidikan dasar dan pendidikan menengah. Peraturan Menteri Pendidikan dan Kebudayaan, 5,1-6.

Yeni, E. M. (2011). Pemanfaatan benda-benda manipulatif untuk meningkatkan pemahaman konsep geometri dan kemampuan tilikan ruang siswa kelas V sekolah dasar. Jurnal Edisi Khusus, 1, 6375 .

Mulyati, D., \& Nugrahani, F. (2020). Pengembangan Bahan Ajar Membaca Permulaan Berbasis Media Flash Card Variatif Untuk Sekolah Dasar. Stilistika: Kajian Bahasa, Sastra, dan Pembelajarannya, 5(1), 9-18.

Nomleni, F. T., \& Manu, T. S. N. (2018). Pengembangan media audio visual dan alat peraga dalam meningkatkan pemahaman konsep dan pemecahan masalah. Scholaria: Jurnal Pendidikan dan Kebudayaan, 8(3), 219-230.

Pakungwati, I. F., Ellianawati, E., \& Fianti, F. (2018). Dampak Penguatan Apersepsi dan Pemberia Tugas Terhadap Penguasaan Konsep Siswa. UPEJ Unnes Physics Education Journal, 7(3), 11-17.
Prasetyarini, A., Fatmaryanti, S. D., \& Akhdinirwanto, R. W. (2013). Pemanfaatan alat peraga IPA untuk peningkatan pemahaman konsep fisika pada siswa SMP Negeri I Buluspesantren Kebumen tahun pelajaran 2012/2013. RADIASI: Jurnal Berkala Pendidikan Fisika, 2(1), 7-10.

Prasetyo, G., \& Prasojo, L. D. (2016). Pengembangan adobe flash pada pembelajaran tematik-integratif berbasis scientific approach subtema indahnya peninggalan sejarah. Jurnal Prima Edukasia, 4(1), 54-66.

Rahmaibu, F. H., Ahmadi, F., \& Prasetyaningsih, F. D. (2016). Pengembangan media pembelajaran menggunakan adobe flash untuk meningkatkan hasil belajar PKn. Jurnal Kreatif: Jurnal Kependidikan Dasar, 7(1), 110 .

Sugita, I., Liana, Y. R., Lestari, A. F., Rusilowati, A., \& Subali, B. (2020). Penerapan Model Pembelajaran Relating, Experiencing, Applying, Cooperating, Transferring (REACT) untuk Meningkatkan Pemahaman Konsep Fisika SMA. Physics Education Research Journal, 2(2), 141-150.

Hidayatullah, A. S. (2020). Pengaruh Model Pembelajaran Tandur Dan Media Pembelajaran Adobe Flash Terhadap Hasil Belajar Siswa. Jurnal Pendidikan Teknik Elektro, 9(3), 461-469..

Tafonao, T. (2018). Peranan media pembelajaran dalam meningkatkan minat belajar mahasiswa. Jurnal Komunikasi Pendidikan, 2(2),

103-114. 